\title{
GOOD PRACTICES OF EFFICIENT PACKAGING WASTE MANAGEMENT
}

\author{
Cristian Teodor $^{1 *}$, Carmen Lenuța Trică ${ }^{2}$, Raluca Ignat ${ }^{3}$ \\ and Raluca-Mihaela Drăcea ${ }^{4}$ \\ ${ }^{1223344)}$ The Bucharest University of Economic Studies, Romania
}

\begin{tabular}{|l|l|}
\hline & Please cite this article as: \\
Teodor, C., Trică, C.L., Ignat, R. and Drăcea, R.M., 2020. & Received: 24 March 2020 \\
Good Practices of Efficient Packaging Waste & Revised: 30 April 2020 \\
Management. Amfiteatru Economic, 22(55), pp. 937-953. & Accepted: 5 July 2020 \\
& \\
DOI: 10.24818/EA/2020/55/937 & \\
\hline
\end{tabular}

\begin{abstract}
In the current European context, member states have increasingly effective and efficient concerns in the field of sustainable waste management. To this effect, the European Commission has adopted a package of measures in order to stimulate Europe's transition to a circular economy, which first involves efficient waste management and the consolidation of good practices in the field. Thus, Romania will have to comply with the new European rigors and improve its own waste management system.

This paper aims to identify and analyse a set of good practices in the field of packaging waste in order to design one that is suitable for Romania. These examples are national models for organizing the management of packaging waste through deposit or storage systems. The main objective of these systems is to increase the recycling rates of packaging waste in accordance with European requirements, as well as the sustainable development of the waste sector, without causing economic losses to any of the stakeholders, namely business, population, environment and public authorities.

The paper intends to conceptualize a specific model for the Romanian economy, respectively a model of organization and operation of the deposit system in the field of packaging waste that could be used by the competent authorities and the business environment.
\end{abstract}

Keywords: packaging waste, deposit system, good practices, deposit reimbursement mechanism, Romania

JEL Classification: Q56, R11, O35

\footnotetext{
* Corresponding author, Cristian Teodor - cristian_teodor84@yahoo.ro
} 


\section{Introduction}

Waste management is one of the most important problems of humanity and, implicitly, of the European Union, respectively Romania. The enormous amounts of waste generated by the anthropogenic activity have pushed the planet's ability to absorb them to the upper limits. Finding solutions could have a two-pronged approach: on the one hand, the realization and development of economic activities that generate as little waste as possible, and, on the other hand, the design and implementation of systems that determine the reuse, recycling and use of this waste. For positive results, the two approaches should be implemented simultaneously by all states in the world.

In this context, the European Union has established that one of its priorities should be the circular economy, and the transition to this type of economy should be made concurrently with the increasing of the competitiveness of companies and the sustainable development of the economy (European Commission, 2015). Thus, in 2015, the Commission adopted the First Action Plan for a Circular Economy and all 54 proposed actions were achieved. At the end of 2019, the Commission launched the new Action Plan for a Circular Economy, which includes a special chapter on waste recovery and the creation of markets for by-products (European Commission, 2020). The European Environmental Pact has also been launched, setting out clear rules for this (European Commission, 2019).

The common goal is to turn Member States' economies into circular economies in which waste is no longer seen as a burden but, on the contrary, perceived as reusable waste or raw materials. Its reintroduction into the industrial process would lead to a substantial decrease in the amount of stored waste. Its capitalization would materialize through reindustrialization with innovative, clean technologies that would determine the obtaining of new diversified finished products. We will always find innovative solutions so as to manage municipal waste in an efficient manner (Banacu, et al., 2019), and the authorities will solve the subsequent restrictions by using the very instruments provided by the academic environment. (Busu and Trica, 2019).

In this context, our country is obliged to comply with the new European rigors and improve the performance of its own waste management. The application and implementation of the deposit system in different Member States of the European Union have led to substantial increases in the achievement of waste collection targets set by the Community environmental policy, in the context in which the society and producers are required to participate jointly in achieving a single goal, namely to "build a recycling society".

Over the course of time and space, Member States have responded differently to all these measures: some have introduced clear waste management systems, while others did not use the environmental tools at their disposal. For example, some countries apply the deposit system to beverage packaging, which differs for glass and / or packaging, with outstanding refund rates in Denmark of $98 \%$ and in Germany from $43 \%$ for Polyethylene Terephthalate (PET) to $82 \%$ for glass. There are also some Member States that have not yet resorted to these deposit systems, as is the case of Romania and Spain, where there is a tendency to oppose these interventions. The behaviour is justified by the reluctance of the companies to financially support these systems, on the one hand, and, on the other hand, by the demographic reality, with regional discrepancies and large differences in different consumption behaviours between rural and urban areas. 
Just like other Member States that have not implemented the landfill system for packaging waste, Romania has deficiencies as well, according to the recycling rates reported by the National Environmental Protection Agency, in meeting the targets set by the Directive (EU) 2019/904 on management waste.

In order to achieve this goal of becoming a recycling society, there is practically a need to involve the whole society (companies, citizens, education system, environmental NGOs, etc.). Awareness of the need for social responsibility in the field of packaging waste management can be achieved through direct and indirect administrative measures that can lead citizens to become more attentive to issues that are really important to them and to future generations.

The main objectives of the paper refer to the following: systematization of the European and national legal framework in the field of waste, analysis and comparison of European models of organization and operation of deposit systems; identifying a set of good practices in the field of packaging waste at European level; and conceptualizing a model for organizing a functional deposit system for Romania.

This paper is divided into four parts, the Chapter European and national legislative framework on packaging waste management summarizes the main legislative aspects of waste management, in order to highlight the obligations of each Member State to act to achieve European labels. The second part, Conceptual and operational aspects of deposit systems, refers to the actual content of a deposit system, its objectives, the limits and advantages of its operation and implementation. Part Three Models of operation of deposit systems in the European Union summarizes the organization and operation of deposit systems at the level of European states, using the same analysis criteria, in order to highlight the advantages of each system. The last part of the paper defines a deposit system for Romania, so that a harmonization of all the wishes and needs of all stakeholders can be achieved.

The approach of this paper, with reference to the management of packaging waste, is a pragmatic one, in order to offer a pertinent and perfectly articulated solution to the Romanian economy and society.

\section{European and national legislative framework on packaging waste management}

The European Commission has adopted, in December 2015, a package of measures aimed at stimulating the transition to a circular economy. The package of measures includes proposals for the revision of waste legislation and a related action plan.

The legislative proposals on waste include many long-term objectives for reducing waste and increasing the recycling and reuse of waste, and the revised Directives following the implementation of the package of measures are: Directive 2008/98/EC on the waste hierarchy and Directive 94/62/EC on packaging and packaging waste.

The circular economy action set supports these legislative proposals aimed at closing the circular economy loop, targeting all stages of a product's life cycle: from consumption to waste management and to the secondary raw materials market.

The main proposals for revising the legislative framework contained in the circular economy package include: 
- recycling of $65 \%$ of the weight of all packaging waste by 2025 and of at least $75 \%$ by 2030 , (with an intermediate target of $65 \%$ in 2025);

- prohibition of storage of separately collected waste;

- promoting indirect (economic) instruments to discourage waste disposal;

- reuse and stimulation of industrial symbiosis;

- economic incentives for manufacturers to place green products on the market and support recycling and recovery schemes (e.g. for packaging, batteries, electrical and electronic equipment, vehicles).

The most important documents necessary to fulfil the obligations assumed by Romania as a member country of the European Union are the National Waste Management Strategy and the National Waste Management Plan. These were carried out on the basis of the European and national legislative support in the field and aim to create the necessary framework for the implementation of an integrated waste management system, part of the circular economy. In order to respond to the circular economy package proposed by the European Commission, the Romanian authorities decided to implement the following environmental principles: pay for what you throw away, extended producer responsibility and storage tax.

The national environmental legislation contains some amendments to the main waste management legislation, so that, taking into account both EU-level changes and business constraints, the authorities have developed a package of measures. The most current and important changes focus on the increased recycling targets for all types of packaging waste.

The most current and important legislative act in Romania is the Government Emergency Ordinance no. 74/2018 of July 17, 2018 for the amendment and completion of Law no. $211 / 2011$ on the waste regime, of Law no. 249/2015 on the management of packaging and packaging waste and Government Emergency Ordinance no. 196/2005 on the Environmental Fund. This Ordinance contains legislative changes in the field of packaging and packaging waste management. The most important amendments concern the following issues:

- increasing the recycling rates of packaging waste;

- application of the principle of extended producer responsibility;

- adjustment of the measures for individually fulfilling the recycling rates of packaging waste starting with January 1, 2019, namely, only through the management of own packaging placed on the market;

- introduction of the deposit -return system for unusable primary packaging;

- increasing the sanctions applied for the non-fulfilment of the obligations of the parties involved in the management of packaging and packaging waste;

- introducing the contribution to the circular economy and reducing its amount.

It is particularly important, in the current socio-economic context, for Romania to take all the necessary steps to achieve these imposed goals, both with the effort of the authorities not to hinder the activity of economic agents, but to create all the conditions for the sustainable development of the companies. On the other hand, companies will make every 
effort to fulfil the ethical dimension of their business (Dinu, 2008). Any of the tools used by the national authorities must be in the interest of companies, their customers and the natural environment. From this perspective, the European economies have decided to use the deposit system, which meets all the requirements of environmental protection, the production and consumption model specific to the circular economy, the needs of private companies and the consumption model of the citizen.

\section{Conceptual and operational aspects of deposit systems}

The deposit refund system (DRS) is a way in which the various parties involved in the producer-consumer-recycler chain organize a system of voluntary return of packaging, single use or reusable, using a financial incentive (deposit) (Teodor, et al., 2020). The consumer pays a sum of money (deposit) when buying a product packaged in returnable packaging and recovers his deposit when returning the packaging in one of the arranged collection centres. The advantages of using the deposit system are shown in Table no. 1:

Table no. 1. The advantages of using the deposit system

Ecological perspective
-a great advantage is the substantial decrease
of the phenomenon of abandonment of
packaging waste (littering) in the states
where the deposit system was introduced, a
phenomenon that seriously affects Romania;
- increasing the aggregate recycling and
recovery rates of waste at national level by
improving the recycling and recovery rates of
packaging.
- the polluter pays principle is applied, so
whoever does not take the packaging back,
bears the cost, respectively the deposit

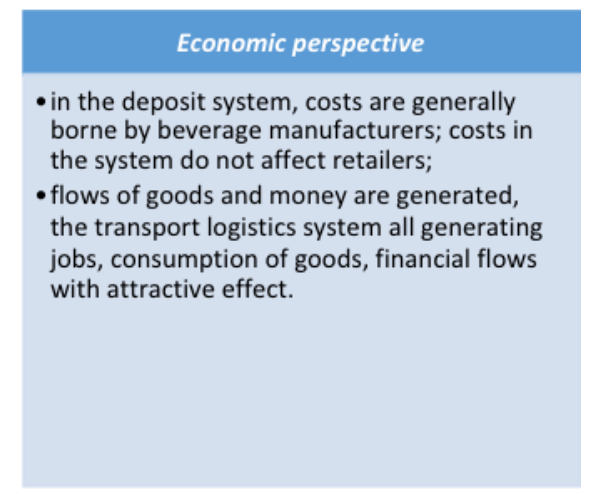

Source: Teodor, et al., 2020, p. 5

From the experience of European and non-European states that have implemented the deposit system, it results that only certain categories of packaging waste are usually part of this system, namely:

a) unusable plastic packaging:

- PET packaging, single-ply, weak alcoholic beverages <31;

- PET packaging, single-ply, water and soft drinks <31;

- PET packaging, single-ply, transparent, milk <31;

- HDPE milk packaging, soft drinks and fruit juices <31.

b) unusable glass packaging:

- glass packaging weak alcoholic beverages <31;

- water glass packaging, soft drinks and fruit juices <31. 
c) metal packaging:

- Al packaging, weak alcoholic beverages <1.5 1;

- Al packaging, soft drinks $<1.51$;

- Fe and alloy packaging, weak alcoholic beverages $<1.51$;

- Fe and alloy packaging, soft drinks $<1.51$.

From a theoretical point of view, any category of packaging can be covered by the deposit system, but, in practice, this system can currently only integrate part of these categories.

The deposit system has some limitations in terms of its implementation and operation, among which we mention:

- the introduction of a phased deposit system cannot include all packaging at once, and the effect on the environment by eliminating littering is long-lasting, not spontaneous;

- in a first stage of the introduction of the deposit system, the costs of the producers whose products and packaging are covered by the deposit system increase;

- in the first part there will be an increase in the price of the products on the shelf, with the value of the deposit;

- there is a risk that some consumers will be discouraged from buying the product, due to the increase in the shelf price with the value of the deposit.

Like any other economic system, this deposit system can have economic-financial and social vulnerabilities:

- decrease in demand, in the short term, for products whose packaging is covered by the deposit system;

- the logistics / transport system will be very extensive for the packaging received in the warranty system and may have weaknesses in its operation, given the conditions of national roads;

- the marks used to mark the packaging included in the deposit system may suffer technical and technological damage;

- the disinterest of the economic agents that support the deposit system for the financial support of the system, at least in the initial phase.

One of the options for operationalizing the deposit system would be the "One Way" system, which consists in paying a mandatory deposit/deposit for returnable "one way" packaging for beverages; it is found in some countries, such as Scandinavia, the East Coast, California and Germany. Another model of a possible deposit system that can be implemented in Romania is presented in the form of a body that does not seek to obtain a profit that includes the flow of materials, financial flow and infrastructure. 


\section{Operational models of deposit systems in the European Union}

The main objective of this section is to characterize the models of operation of deposit systems in some European countries, in order to identify the main common features necessary for a model proposed for Romania. The criteria according to which the deposit systems already implemented are analysed are: recovery rates, return rates, recovery targets, the value of the deposit for the targeted packaging, the organization of the body that manages the system.

For a clearer perspective on the economic and social environment in which these systems operate, it is important to clarify some important issues regarding demography, circular economy indicators and more.

The demographic aspects are particularly important to be taken into account in the analysis of the functioning of deposit systems, because the scheme of operation of deposit systems may depend on the total population, the environment of residence, the way of life and the consumption behaviour of the population.

Good practice is based on these indicators, because the residence environment requires different consumer behaviours and, implicitly, deposit systems are different or need to be organized differently in order to be functional and efficient.

Thus, as can be seen from the data presented in Table no. 2, during 2008-2018, the share of the population in urban areas is up to $60 \%$ of the total population in countries such as Slovakia, Romania, Slovenia, Croatia, Austria and Poland and over $80 \%$ in Finland, Sweden, Denmark, Luxembourg, the Netherlands, Malta and Belgium, well above the EU 28 average of the range, of $73.54 \%$ (Figure no. 1). Interestingly enough, both categories of states have both large and small populations, which requires that good practices of deposit systems be thought of according to the environment of residence and not according to the total population.

Table no. 2. Urban population (\% of total pollution) in the EU 28

\begin{tabular}{|l|l|l|l|l|l|l|l|l|l|l|l|}
\hline $\begin{array}{l}\text { Country/ } \\
\text { Year }\end{array}$ & $\mathbf{2 0 0 8}$ & $\mathbf{2 0 0 9}$ & $\mathbf{2 0 1 0}$ & $\mathbf{2 0 1 1}$ & $\mathbf{2 0 1 2}$ & $\mathbf{2 0 1 3}$ & $\mathbf{2 0 1 4}$ & $\mathbf{2 0 1 5}$ & $\mathbf{2 0 1 6}$ & $\mathbf{2 0 1 7}$ & $\mathbf{2 0 1 8}$ \\
\hline Slovakia & 55.11 & 54.96 & 54.69 & 54.42 & 54.28 & 54.14 & 54.00 & 53.89 & 53.81 & 53.75 & 53.73 \\
\hline Romania & 53.57 & 53.70 & 53.83 & 53.96 & 53.97 & 53.94 & 53.90 & 53.89 & 53.90 & 53.94 & 54.00 \\
\hline Slovenia & 52.21 & 52.43 & 52.66 & 52.88 & 53.11 & 53.33 & 53.56 & 53.78 & 54.02 & 54.27 & 54.54 \\
\hline Croatia & 54.82 & 54.99 & 55.16 & 55.32 & 55.51 & 55.71 & 55.92 & 56.16 & 56.40 & 56.67 & 56.95 \\
\hline Austria & 57.97 & 57.68 & 57.40 & 57.12 & 57.15 & 57.34 & 57.53 & 57.72 & 57.91 & 58.09 & 58.30 \\
\hline Poland & 61.12 & 61.00 & 60.89 & 60.78 & 60.65 & 60.53 & 60.40 & 60.28 & 60.18 & 60.11 & 60.06 \\
\hline Ireland & 61.14 & 61.34 & 61.54 & 61.74 & 61.94 & 62.14 & 62.34 & 62.54 & 62.74 & 62.95 & 63.17 \\
\hline Portugal & 59.36 & 59.96 & 60.57 & 61.17 & 61.76 & 62.35 & 62.94 & 63.51 & 64.09 & 64.65 & 65.21 \\
\hline Cypus & 67.84 & 67.70 & 67.55 & 67.41 & 67.26 & 67.14 & 67.03 & 66.95 & 66.88 & 66.84 & 66.81 \\
\hline Lithuania & 66.85 & 66.84 & 66.76 & 66.74 & 66.86 & 66.99 & 67.11 & 67.23 & 67.37 & 67.52 & 67.68 \\
\hline Latvia & 67.83 & 67.81 & 67.84 & 67.87 & 67.90 & 67.93 & 67.95 & 67.98 & 68.02 & 68.08 & 68.14 \\
\hline Estonia & 68.35 & 68.22 & 68.09 & 67.97 & 67.97 & 68.12 & 68.27 & 68.42 & 68.56 & 68.72 & 68.88 \\
\hline Italy & 68.09 & 68.21 & 68.33 & 68.44 & 68.68 & 68.98 & 69.27 & 69.57 & 69.86 & 70.14 & 70.44 \\
\hline Hungary & 67.94 & 68.46 & 68.91 & 69.36 & 69.68 & 69.95 & 70.23 & 70.50 & 70.78 & 71.06 & 71.35 \\
\hline $\begin{array}{l}\text { Czech } \\
\text { Republic }\end{array}$ & 73.39 & 73.32 & 73.26 & 73.19 & 73.20 & 73.29 & 73.38 & 73.48 & 73.57 & 73.68 & 73.79 \\
\hline Bulgaria & 71.62 & 71.96 & 72.30 & 72.64 & 72.98 & 73.31 & 73.65 & 73.99 & 74.33 & 74.67 & 75.01 \\
\hline Germany & 76.58 & 76.77 & 76.97 & 77.16 & 77.17 & 77.18 & 77.19 & 77.20 & 77.22 & 77.26 & 77.31 \\
\hline Greece & 75.57 & 75.93 & 76.29 & 76.65 & 77.00 & 77.36 & 77.70 & 78.05 & 78.39 & 78.72 & 79.06 \\
\hline
\end{tabular}




\begin{tabular}{|l|l|l|l|l|l|l|l|l|l|l|l|}
\hline $\begin{array}{l}\text { Country/ } \\
\text { Year }\end{array}$ & $\mathbf{2 0 0 8}$ & $\mathbf{2 0 0 9}$ & $\mathbf{2 0 1 0}$ & $\mathbf{2 0 1 1}$ & $\mathbf{2 0 1 2}$ & $\mathbf{2 0 1 3}$ & $\mathbf{2 0 1 4}$ & $\mathbf{2 0 1 5}$ & $\mathbf{2 0 1 6}$ & $\mathbf{2 0 1 7}$ & $\mathbf{2 0 1 8}$ \\
\hline Spain & 77.98 & 78.21 & 78.44 & 78.67 & 78.90 & 79.13 & 79.37 & 79.60 & 79.84 & 80.08 & 80.32 \\
\hline France & 77.87 & 78.12 & 78.37 & 78.62 & 78.88 & 79.14 & 79.39 & 79.66 & 79.92 & 80.18 & 80.44 \\
\hline $\begin{array}{l}\text { Great } \\
\text { Britain }\end{array}$ & 80.76 & 81.03 & 81.30 & 81.57 & 81.84 & 82.10 & 82.37 & 82.63 & 82.89 & 83.14 & 83.40 \\
\hline Finland & 83.30 & 83.43 & 83.77 & 84.31 & 84.84 & 85.13 & 85.18 & 85.23 & 85.28 & 85.33 & 85.38 \\
\hline Sweden & 84.75 & 84.90 & 85.06 & 85.30 & 85.62 & 85.94 & 86.25 & 86.55 & 86.85 & 87.15 & 87.43 \\
\hline Denmark & 86.49 & 86.65 & 86.80 & 86.96 & 87.14 & 87.29 & 87.41 & 87.53 & 87.64 & 87.76 & 87.87 \\
\hline $\begin{array}{l}\text { Luxembo } \\
\text { urg }\end{array}$ & 87.80 & 88.18 & 88.55 & 88.91 & 89.25 & 89.57 & 89.88 & 90.18 & 90.46 & 90.73 & 90.98 \\
\hline $\begin{array}{l}\text { Netherlan } \\
\text { ds }\end{array}$ & 85.40 & 86.29 & 87.13 & 87.88 & 88.59 & 89.19 & 89.69 & 90.17 & 90.64 & 91.08 & 91.49 \\
\hline Malta & 93.93 & 94.00 & 94.07 & 94.14 & 94.21 & 94.28 & 94.35 & 94.41 & 94.48 & 94.55 & 94.61 \\
\hline Belgium & 97.56 & 97.60 & 97.65 & 97.70 & 97.74 & 97.79 & 97.83 & 97.88 & 97.92 & 97.96 & 98.00 \\
\hline EU-28 & $\mathbf{7 2 . 5 6}$ & $\mathbf{7 2 . 7 6}$ & $\mathbf{7 2 . 9 7}$ & $\mathbf{7 3 . 1 7}$ & $\mathbf{7 3 . 3 6}$ & $\mathbf{7 3 . 5 4}$ & $\mathbf{7 3 . 7 2}$ & $\mathbf{7 3 . 9 1}$ & $\mathbf{7 4 . 1 1}$ & $\mathbf{7 4 . 3 1}$ & $\mathbf{7 4 . 5 2}$ \\
\hline
\end{tabular}

Source: World Bank, 2018

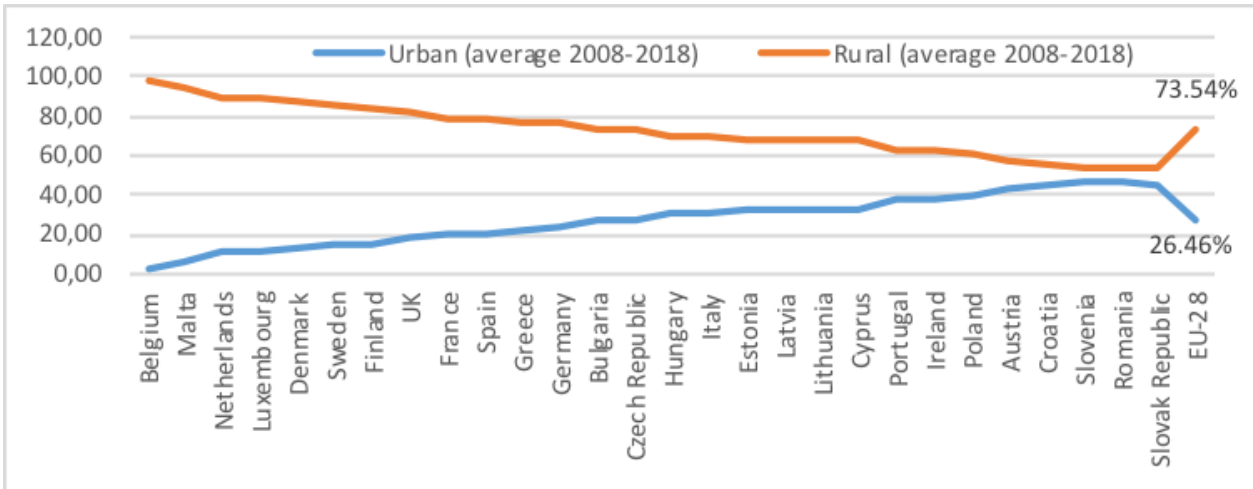

Figure no. 1. Urban and rural population

(average 2008-2018, \% of total population) in EU 28

Source: World Bank, 2018

Regarding the first indicator of the circular economy (recovery rate of packaging waste), it is noted that, in 2017, except Croatia and Malta, all the other countries reached and far exceeded the target of $60 \%$ (target to be reached in 2015) (Figure no. 2). According to Eurostat data, Finland has the highest recovery rate (112.1\% in 2017), the rate being explained by the storage of waste generated in previous years. Also, countries such as Germany, Belgium, Denmark, Luxembourg and the Netherlands have recovery rates well above the EU-28 average ( $80.1 \%$ in 2017).

At the level of 2017, the lowest recovery rates were recorded in Malta (39.7\%), Croatia $(50.5 \%)$, Hungary (60.1\%), Poland (60.8\%), Latvia (60.9\%) and Romania (62.3\% in 2016).

Thus, we can observe that although Romania had an average rate for the period 2008-2017 of only $47.76 \%$, it managed to reach the target set one year later than the provisions of Article 6 of the EU Packaging Waste Directive (the targets set for 2008 were to be met by all states in 2015). 


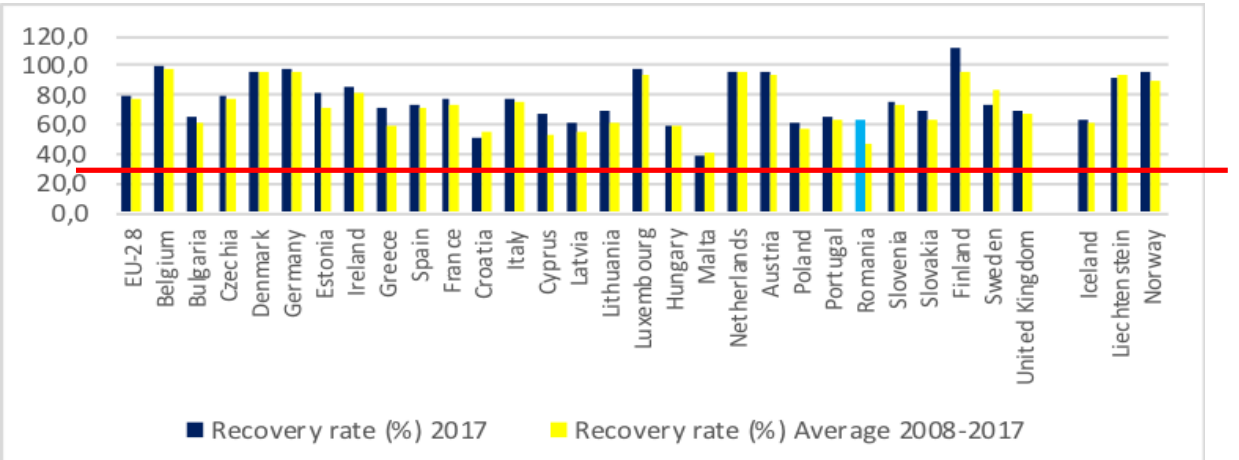

Figure no. 2. Recovery rate of packaging waste (2017 and average 2008-2017, \%) Source: Own preparation using EUROSTAT

https://appsso.eurostat.ec.europa.eu/nui/submitViewTableAction.do *Estimate (2016 data)

Regarding the second indicator of the circular economy (recycling rate), from the data presented in Figure no. 3, it is noted that, in 2017, Belgium has the highest recycling rate $(83.8 \%)$ and together with other countries with rates between $70 \%$ and $80 \%$ (Slovenia: 70.1\%; Sweden: 71.7\%; The Netherlands: 78.1\%; Denmark: 74.8\%) contributes to the sustainability of the deposit system.

The lowest recycling rates were recorded in 2017 in Malta (39.7\%), Iceland (46.8\%), Hungary (49.7\%), Croatia (50.5\%), Estonia (53.5\%), Portugal (55.3\%), Poland

(56.7\%) and Latvia (58.7\%). Regarding Romania, although the average for the period $2008-2017$ is below $60 \%(49.79 \%)$, in 2016 it reached the set target $(60.4 \%)$.

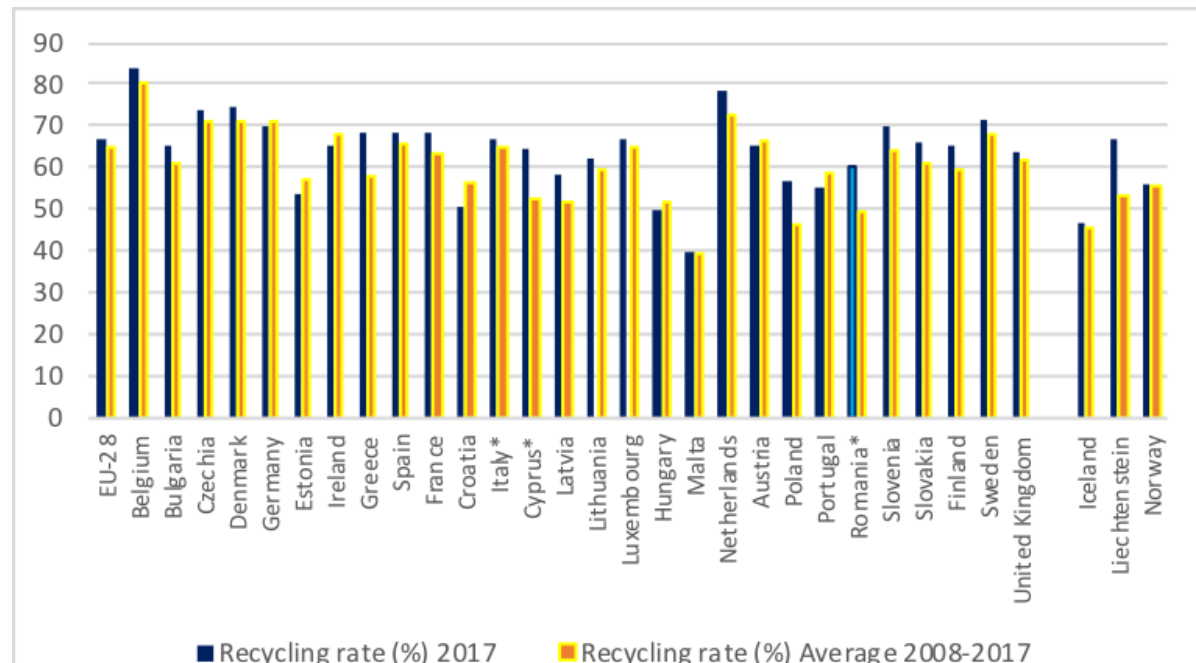

Figure no. 3. Recycling rate of packaging waste (2017 and average 2008-2017, \%)

Source: Own preparation using EUROSTAT

https://appsso.eurostat.ec.europa.eu/nui/submitViewTableAction.do

*Estimate (2016 data) 
These indicators demonstrate the need for the states to approach in a different manner the issue of packaging management and the organization of a deposit system model.

At the level of the European Union and Europe in general, there are many models of how deposit systems work. The differences between them are from all perspectives, from the ownership of the system to the operating model, from the ownership of the packaging to the financial flow.

The oldest deposit system is the one in Sweden, which was adopted in 1981 for aluminium packaging, was completed in 1991 for PET and in 2005 for plastic. The system had a reception rate of $88.5 \%$ in 2014 , but targeted $90 \%$. The deposit charged is 0.11 euro to 0.22 euro/package. The system is $95 \%$ automated and $5 \%$ manual and is managed by a private company.

The deposit system in the Netherlands is more recent than in Sweden, being adopted in 2003 and entered into force in 2005. Already in 2014 it received 95\% of PET packaging and aimed to receive $95 \%$ of all packaging that is included. It works with a deposit of 0.25 euro/packaging and is $89 \%$ automated, the remaining $11 \%$ being manual. The system, just like the one in Sweden, is managed by an economic operator.

In one of the three Baltic countries, Estonia, the deposit system was approved in 2004 and became operational in 2005 , and covers approximately $82.5 \%$ of packaging, compared to a proposed target of $85 \%$. The deposit charged is 0.11 euro/package, regardless of the shape, material or volume. The system operator is a representative of the manufacturers and $96 \%$ of the system is automated, only $6 \%$ being manual. Obviously, when identifying this information, we must corroborate it with the national specifics: the surface of the country, the population density, the degree of urbanization, etc.

Germany is a state with a special form of deposit system, which works completely differently from other systems in different countries, because it is the retailer that has the main role in managing the deposit system. This is an exclusive feature of the German system, as, in the other states, the producers are the ones in charge of managing the deposit system. In these states, the polluter pays principle is respected, because it is the producers who bring the packaging on the market. From this perspective, the German deposit system works in other conditions. The system started operating in 2003 under the authority of the Ministry of Environment. The deposit is 0.25 euros, regardless of the type of packaging. The German system operates decentralized.

The deposit system in Lithuania has been introduced since 2016 under the authority of the Ministry of Environment, as in the case of Germany. It receives $74 \%$ of the amount of packaging placed on the market and targets $90 \%$ by 2025 . The value of the deposit is 0.10 euros. The administration of the system is a governmental one.

In the case of the Czech Republic, this deposit system is still being analysed in order to be able to be implemented, with some studies supporting it and others combating it. The main environmental and economic benefits for its implementation are recognized by the authorities in the field, but a final decision has not yet been taken.

At EU28+ level, the European Free Trade Association operates 10 deposit systems, with the eleventh in preparation (Slovakia). Success rates for return are between $87 \%$ (Croatia) and over $96 \%$ (Norway and Germany - without glass packaging). Apart from Croatia (state system) and Germany (decentralized system), the other storage systems are based on the 
private input of producers or associations of producers and bottlers of water, soft drinks and beer together with recyclers, retailers of various types.

Taking into account the implementation of the deposit system in different European and non-European states presented above, there is a need to identify new niches for economic development in order to obtain social and environmental benefits. Informing the public about the recycling of packaging waste plays an important role in designing sustainable business models. In this sense, the transition from the theoretical approach of the circular economy to its implementation requires the support of the process of industrial symbiosis, both physically and electronically. Among the good practices at European level we can highlight the following:

- design of packaging with recycling potential,

- stimulate the demand for recycled plastics by developing quality standards on the sorting of plastic waste and recycled plastics and take action on eco-labelling and green public procurement,

- selective collection of packaging waste - national, regional and local authorities, in cooperation with waste management operators, having an important role in raising public awareness and ensuring high quality selective collection,

- promoting and using economic incentives for producers who place green products on the market and support the recycling and recovery rates of packaging waste in accordance with European legislation,

- designing an online platform encouraging the exchange of waste between platform members, to reduce the amount of stored waste, to develop new business opportunities.

\section{Conceptualization of a deposit system for waste packaging in Romania}

Romania must achieve important steps in the direction of the circular economy by recycling packaging waste, respectively by applying a national model of good practice, which will actively contribute to the design of new sustainable business models.

For Romania, an example of good practices in the field of packaging waste is the introduction of a deposit system for certain categories of waste.

The packaging waste existing on the market in 2017, according to the reports of the Environmental Fund Administration, is about 1.7 million tonnes, representing a recycling rate of about $60 \%$. Of the total packaging waste, the waste categories that were reported for 2017 are:

- Packaging waste from Polyethylene terephthalate (PET): 132,900 tonnes introduced, of which 73,259 tonnes were recycled $(55 \%)$; for the rest of the plastic packaging, the recycling rate was below $40 \%$;

- Aluminium packaging waste: 23,355 tonnes introduced, of which 5,811 tonnes were recycled (only $25 \%$ );

- Glass packaging waste: 270,202 tonnes were introduced, of which 170,985 tonnes were recycled $(63 \%)$. 
In total, the recycling rate of packaging waste subjected to the deposit system is about $60 \%$, all three categories of packaging having a recovery rate below the minimum target imposed by GEO74/2018. An unfavourable situation is recorded in the case of aluminium packaging.

If we take into account the quality level (intensity) of the phenomenon of garbage dumped on the public roads (littering) - the overall average grade is 2.97 , i.e. highly polluted, $72.4 \%$ of sites are classified as dirty - very dirty - severely polluted, then it can be concluded that the littering phenomenon has a global (national) manifestation and its intensity is high. According to the grid adopted for assessing the extent of the phenomenon - the national average level is characterized by an index $4(80 \%)$, which corresponds to an embarrassing presence of litter pollution in proportion of 4 locations out of 5 , as can be seen from the results of the June-July 2010 campaigns (CEDD, 2010).

The littering composition is also worrying. In 2009 , approximately $42 \%$ of the composition of abandoned waste consisted of PET, glass beverage packaging and aluminium cans. In 2010 , beverage packaging was also the majority, both in terms of volume and weight (excluding the construction and demolition waste), although the methodology had changed.

Beverage packaging accounted for $23.5 \%$ of the total waste composition and $33.57 \%$ of the weight. These figures are in line with other evaluations in international studies.

Therefore, the introduction of a deposit system in Romania will have a significant impact in reducing the littering. By assigning a value to the packaging, we can witness a decrease in the amount of packaging thrown into the environment. In this context, more than 100,000 tonnes of packaging, estimated annually as litter, could no longer end up in the environment, being instead recycled.

From the data presented, it results that the operationalization of a deposit system in Romania will have a significant impact in terms of reducing greenhouse gases $(\mathrm{CO} 2)$. The table below presents the estimates regarding the environmental impact in the event of the introduction of the deposit system in Romania (table no. 3).

Table no 3. Estimation of the impact

of deposit system implementation in Romania

\begin{tabular}{|l|r|r|r|}
\hline Package type & $\begin{array}{c}\text { Tonnes returned } \\
\text { in deposit system } \\
\text { (average for } \\
\text { 24 years), t/year }\end{array}$ & $\begin{array}{l}\text { CO2/tonne } \\
\text { of package }\end{array}$ & $\begin{array}{c}\text { Annual amount } \\
\text { of emission } \\
\text { reduction, t CO2 }\end{array}$ \\
\hline PET & 93,241 & 1.5 & 139,862 \\
\hline Aluminium & 11,721 & 6.5 & 76,187 \\
\hline Glass & 461,098 & 0.1 & 46,109 \\
\hline \multicolumn{1}{|c|}{ Total } & $\mathbf{5 6 6 , 0 6 1}$ & & $\mathbf{2 6 2 , 1 5 8}$ \\
\hline
\end{tabular}

Source: Teodor, et al., 2020, p. 69

By introducing the deposit system in Romania, over 260,000 tonnes of CO2 can be saved annually. This is the equivalent of burning 120,000 tonnes of coal (which is the annual consumption of a cement plant) or the emissions of about 120,000 cars per year, at an average of $15,000 \mathrm{~km} / \mathrm{year} / \mathrm{car}$ and $150 \mathrm{~g} \mathrm{CO} 2 / \mathrm{km}$ (Teodor, et al., 2020). 
A deposit system proposed for Romania could have several flows for its correct functioning: packaging flows or material flows, cash flows, respectively for the deposit circuit.

The stages of the flow of materials, respectively of the packaging waste of the products purchased and targeted by the system are:

- Manufacturers shall market beverages packaged in different categories of packaging included in the deposit system, receiving the value of the product and, separately, the deposit for that packaging from the retailer.

- The retailer sells to the final consumer beverages packaged in different categories of packaging included in the deposit system, collecting the value of the product and, separately, the deposit for that packaging.

- The consumer purchases the product from the retailer and returns to the collection points of the packaging after consuming the product/content.

- Packets from collection points shall be transported to the counting centres belonging to the central system.

- Packaging waste is transported from the counting centres to recycling/recovery companies.

- Recycling/recovery companies treat packaging waste, turning it into raw material for the production of other packaging.

- The package holder is the central system.

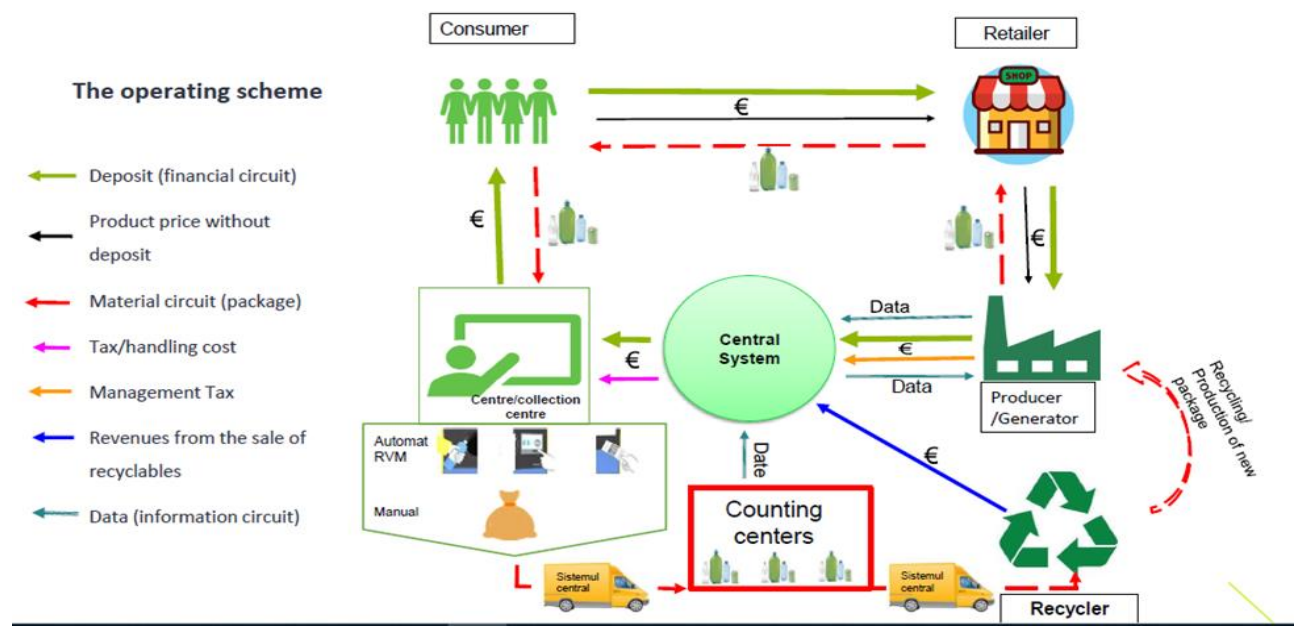

Figure no. 4. Conceptual model for deposit system being proposed for Romania Source: Teodor, et al., 2020, p. 71 
On the other hand, the mechanism for reimbursing the deposit consists of:

- The consumer purchases the packaged product and pays the deposit related to the retailer's packaging; the value of the deposit is clearly distinguished from the price.

- After returning the package to a collection centre, the consumer receives the value of the deposit back. Only those packages recognized by the collection centres as belonging to the system are settled. The manufacturer/generator pays the system the value of the deposits related to the number of pieces of packaging, which are part of the system of deposits, actually sold on the Romanian market during a certain period.

- The retailer pays the manufacturer's warranty when purchasing the product.

- The central system shall provide and issue the deposit to the collection centres.

This deposit must be large enough to be attractive and small enough so as not to affect the sales volume of products covered by the deposit system. At the same time, unrecovered deposits are included in the system's revenues, being as a $100 \%$ deposit rate cannot be returned.

The central system is non-profit, which alone manages the entire system of physical collection of packages and financial compensations for the consumer. He owns and uses packaging waste, manages and ensures the coverage of all operating costs of the deposit system.

The central system is financed from the following sources:

- management fees borne by producers/importers;

- deposits unrecovered by consumers;

- recycled waste;

- other sources

The central system is the one that invests and provides collection equipment and infrastructure. The costs of the central system are:

- own operating costs: salaries, offices, administrative, etc.

- costs of operating, transporting and handling waste in collection centres (automated or manual) and in regional counting centres;

- marketing and communication costs.

The central system will operate with its own headquarters, with its own regulations and will be independent in the decisions it will take regarding the entry and exit of operators from the deposit system. The central system should be the entity provided by the Romanian legislative framework, but which should be financially and organizationally independent, in order to ensure the increase of the efficiency of its operationalization and to achieve the balance between producer and consumer, of any nature, on the targeted markets. The central system is responsible for storing and verifying the data of packaging records from manufacturers and the degree of collection. 
A deposit system must be a hermetically sealed circuit for the eventual entries of packaging that does not belong to the system, fraud being thus eliminated. The system must also be flexible and measurable, adaptable to new consumer requirements, needs in continuous transformation, but to be able to cover the logistical needs of its component parts, and the user interface must be friendly and intuitive.

The introduction of a deposit system in Romania to cover the categories of packaging (glass, metal and plastic) targeted by the deposit system, has several advantages from an ecological point of view, namely: the abandonment rate of packaging waste in the public space registers a significant reduction, promoting a responsible behaviour and reducing the greenhouse gas emissions.

\section{Conclusions}

The main conclusions that emerge from this article are the following:

- There is no one-size-fits-all deposit system for all Member States of the European Union, as each Member State has started at different times, applying them to different packaging and different functions, including the organization of national public authorities.

- National models of deposit systems differ depending on specific features: population, consumption behaviours, home environment, level of economic development, because there are large demographic and economic differences between states.

- The deposit system in Romania cannot target, at this moment of economic and social development, all packaging, but only aims at PET packaging. Obviously, this can be an example of multiplication for other packaging as well.

- Compared to the current linear system in which the principle of extended liability of the manufacturer is applied, the deposit system respects the principle the polluter pays, because the one who does not return the packaging from the system, bears the costs, as he does not recover his deposit.

- By implementing the deposit system in Romania, a series of advantages is obtained, such as: each packaging becomes a source of income for those who own it; the phenomenon of abandonment of PET, glass and aluminium packaging waste will be substantially reduced; the phenomenon of soil pollution will be eliminated by abandoning the PET, glass and aluminium packaging waste; the visual discomfort created by the mountains of PET, glass and aluminium packaging waste that are found on the outskirts of localities, in tourist areas and along the roads and railways, riverbeds and even in the Danube Delta, will be eliminated; some areas that are no longer promoted from this perspective will be presented to the tourist circuit.

All these benefits are obvious and any financial estimate of them is limiting. Their combined effects must be addressed not only economically and financially, but also in terms of population health and from an environmental and social point of view. 


\section{References}

Banacu, C.S., Busu, M., Ignat, R. and Trica, C.L., 2019. Entrepreneurial Innovation Impact on Recycling Municipal Waste. A Panel Data Analysis at the EU Level. Sustainability, [e-journal] 11(18), 5125, pp. 1-13. https://doi.org/10.3390/su11185125.

Bertham, O., Fitzsimons, D., Garcia, T. and Lee, P., 2018. How a deposit scheme for "on the go" could be designed for the UK. [pdf] Oakdene Hollins. Available at: <https://static1.squarespace.com/static/5a60c3cc9f07f58443081f58/t/5ae732756d2a739 e98ff74a8/1525101179114/SUEZ01+463+FINAL.pdf> [Accessed 1 March 2020].

Busu, M. and Trica, C.L., 2019. Sustainability of Circular Economy Indicators and Their Impact on Economic Growth of the European Union. Sustainability, [e-journal] 11(19), 5481. https://doi.org/10.3390/su11195481.

Centrul de Excelență și Dezvoltare Durabilă, 2010. Studiu privind deseurile abandonate in mediu urban si rural - 2009-2010 [online] Available at: <https://issuu.com/ ionutge/docs/brosura_littering_corectata> [Accessed 25 February 2020].

Comisia Europeană, 2015. Inchiderea buclei - un plan de acțiune al UE pentru economia circular, [online] Available at: <https://eur-lex.europa.eu/legal-content/RO/ TXT/HTML/?uri=CELEX:52015DC0614\&from=EN> [Accessed 24 February 2020].

Comisia Europeană, 2019. Pactul ecologic European, [online] Available at: <https://ec.europa.eu/info/strategy/priorities-2019-2024/european-green-deal_ro> [Accessed 22 February 2020].

Comisia Europeană, 2020. Spre o economie circular, [online] Available at: <https://ec.europa.eu/commission/priorities/jobs-growth-and-investment/towardscircular-economy_ro> [Accessed 24 February 2020].

Cordle, M., Elliot, L., Elliot, T., Kemp, S., Sherrington, C. and Woods, O., 2019. A Deposit Refund system for the Czech Republic. [pdf] Eunomia. Available at: <https://www.eunomia.co.uk/reports-tools/deposit-refund-system-czech-republic/> [Accessed 10 March 2020].

Dinu, V., 2008. The ethical dimension of business. Amfiteatru Economic, 10(23), pp.7-8.

Directiva (UE) 2018/851 a Parlamentului European și a Consiliului din 30 mai 2018 de modificare a Directivei 2008/98/CE privind deșeurile, [online] Available at: <http://data.europa.eu/eli/dir/2018/851/oj> [Accessed 8 March 2020].

Directiva 2008/98/CE a Parlamentului European și a Consiliului din 19 noiembrie 2008 privind deșeurile și de abrogare a anumitor directive, [online] Available at: <http://data.europa.eu/eli/dir/2008/98/oj> [Accessed 9 March 2020].

Legea nr. $249 / 2015$ privind modalitatea de gestionare a ambalajelor și a deșeurilor de ambalaje. Bucharest: Romanian Parliament.

Ministerial Order number 1362/2018 on the approval of the authorization procedure, annual approval and withdrawal of the operating right of organizations that implement the obligations regarding the extended liability of the producer. Bucharest: Ministry of the Environment.

Government Emergency Ordinance no. 196/2005 on the Environmental Fund. Bucharest: Romanian Government. 
Government Emergency Ordinance no. 74/2018 of July 17, 2018 for the amendment and completion of Law no. 211/2011 on the waste regime. Bucharest: Romanian Government.

National Waste Management Plan, 2018. Bucharest: Ministry of the Environment.

Government Decision no. 870/2013 on the approval of the National Waste Management Strategy 2014-2020. Bucharest: Romanian Government.

Tellus Institute with Sound Resource Management, 2008. More jobs, less pollution: Growing the recycling economy in the US. [pdf.] Available at: <https://www.nrdc.org/sites/default/files/glo_11111401a.pdf> [Accessed 20 February 2020].

Teodor, C., Bran, M., Ignat, R., Marin, E., Strat, V and Trică, C., 2020. Studiu privind evaluarea sistemului de garanție, componentă a sistemului de gestionare a deșeurilor în România, (Study on the evaluation of the deposit system, component of the waste management system in Romania) [pdf.] Available at: <http://www.mmediu.ro/app/webroot/uploads/files/200311_Brosura-ASE-BuybackPART1\%2BPART2\%20-\%20FINAL.pdf> [Accessed 20 February 2020].

Weghmann, V., 2017. Waste management in Europe. Good jobs in the circular economy? [pdf.], European Public Service Association, Available at: $<$ https://www.epsu.org/sites/default/files/article/files/Waste\%20Management\%20in\%20 Europe.\%20Good\%20Jobs\%20in\%20the\%20Circular\%20Economy\%20for\%20web.pdf $>$ [Accessed 24 February 2020].

World Bank, 2018. Rural population (\% of total population). Available at: <https://data.worldbank.org/indicator/sp.rur.totl.zs> [Accessed 9 March 2020]. 